\title{
Editorial: Research and Reports in Chemistry
}

This article was published in the following Dove Press journal:

Research and Reports in Chemistry

22 February 2017

Number of times this article has been viewed

\section{AM Kannan}

The Polytechnic School, Ira A Fulton Schools of Engineering, Arizona State University, Mesa, AZ, USA

\section{Correspondence: AM Kannan}

The Polytechnic School, Ira A Fulton

Schools of Engineering Arizona State

University, 7I7I E Sonoran Arroyo Mall,

Mesa, AZ 85212, USA

Email amk@asu.edu
Welcome to Research and Reports in Chemistry. We invite authors to submit manuscripts for publication with original results in the fields of science and technology of theoretical, experimental, and practical work on all areas of chemistry. We plan to carry out peer reviews at the shortest possible time to bring out visibility to your research with a turnaround time for the publishing of manuscripts, both for review articles and original research results. Peer reviews are of high quality, and the journal is open access, filling an important niche in the areas of chemistry. Research and Reports in Chemistry provides an interdisciplinary platform for dissemination of information on the science, technology, and commercialization of processes and products, with an emphasis on chemistry. The journal is also open to manuscripts that allow the exchange of ideas, and reviews on chemistry/nanomaterials design and development for various applications related to energy, water, and health, etc. The review articles could consolidate important outcomes of recent research on particular topical areas in any branch of chemistry, critically evaluating challenges/issues and projecting possible research trends/solution. The scope of this journal would also include design and development of tailor-made nanomaterials through green chemistry and their applications toward clean energy generation, storage, utilization, waste heat recovery, and water treatment, as well as sustainability.

\section{Disclosure}

The author reports no conflicts of interest in this work.

Dove Medical Press encourages responsible, free and frank academic debate. The content of the Research and Reports in Chemistry 'Editorial' section does not necessarily represent the views of Dove Medical Press, its officers, agents, employees, related entities or the Research and Reports in Chemistry editors. While all reasonable steps have been taken to confirm the content of each Editorial, Dove Medical Press accepts no liability in respect of the content of any Editorial, nor is it responsible for the content and accuracy of any Editorial.

\section{Publish your work in this journal}

Research and Reports in Chemistry is an international, peer reviewed, open access journal publishing original research, reports, reviews and commentaries on all areas of chemistry. The manuscript management

\section{Dovepress}

system is completely online and includes a very quick and fair peer review system, which is all easy to use. Visit http://www.dovepress.com/ testimonials.php to read real quotes from published authors. 